\title{
Development and Forecasting Drought Indices Using SPI (Standardized Precipitation Index) for Local Level Agricultural Water Management
}

\author{
Motaleb Hossain Sarker ${ }^{1}$, Shamsuddin Ahmed'2, Md. Shadekul Alam², \\ Dilruba Begum², Tariful Newaz Kabir ${ }^{2}$, Rifat Jahan', Md. Monwar-Ul Haq ${ }^{1}$, \\ Syeda Tasbiha Dewan Kabir ${ }^{1}$
}

\footnotetext{
${ }^{1}$ Water Resources Management Division, Center for Environmental and Geographic Information Services, Dhaka, Bangladesh ${ }^{2}$ Bangladesh Meteorological Department (BMD), Dhaka, Bangladesh

Email: motalebsarker@gmail.com, mhsarker@cegisbd.com
}

How to cite this paper: Sarker, M.H., Ahmed, S., Alam, Md.S., Begum, D., Kabir, T.N., Jahan, R., Haq, Md.M.-U. and Kabir, S.T.D. (2021) Development and Forecasting Drought Indices Using SPI (Standardized Precipitation Index) for Local Level Agricultural Water Management. Atmospheric and Climate Sciences, 11, 32-52. https://doi.org/10.4236/acs.2021.111003

Received: June 24, 2020

Accepted: December 14, 2020

Published: December 17, 2020

Copyright $\odot 2021$ by author(s) and Scientific Research Publishing Inc. This work is licensed under the Creative Commons Attribution International License (CC BY 4.0).

http://creativecommons.org/licenses/by/4.0/

\begin{abstract}
Drought is primarily an agricultural phenomenon that refers to conditions where plants are responsive to certain levels of moisture stress that affect both the vegetative growth and yield of crops. It occurs when supply of moisture stored in the soil is insufficient to meet the optimum need of a particular type of crop. Causes of drought in Bangladesh are related to climate variability and non-availability of surface water resources. While it may be possible to indicate the immediate cause of a drought in a particular location, it often is not possible to identify an underlying cause. Therefore, to improve all these services in favour of enhancing agricultural production and reducing food insecurity in Bangladesh, it is mandatory to develop an effective way for disseminating the SPI data indicating drought indices to farmers, and enhance drought and climate resilience. To develop future plan and policy in agricultural sector of Bangladesh, it is vital to understand the previous droughts events with accurate indicators. Since this study will contribute to the agricultural development of Bangladesh therefore there is an obvious need to understand the change of drought frequency all over Bangladesh using a standardized drought index. The main intention of this project is to prepare a proper baseline for forecasting drought indices using SPI data. So, the final outcome of this project would be a knowledge base where a proper forecasting tools and dissemination networks can be updated/developed for farmers.
\end{abstract}

\section{Keywords}

SPI, Drought, Water Management, Climate Adaptation 


\section{Introduction}

Agriculture is the largest sector of the economy in Bangladesh which is highly dependent on climatic phenomena. Despite technological improvement such as improved crop varieties and irrigation system, weather and climate variability are still key factors in agricultural productivity due to climate induced consequences especially the droughts and increasing temperatures. Causes of drought in Bangladesh are related to climate variability and non-availability of surface water resources. Besides this, among the local-level causes are human-induced changes resulting from vegetation loss due to over exploitation of resources and deforestation [1]. Agriculture is the single largest productive sector of the economy and it contributes about $20.83 \%$ to the total gross domestic product (GDP) of the country and employs $48.4 \%$ workforce of the country [2]. Despite important achievement in food grain production and food availability, food security at national, household and individual levels remain a matter of main concern for the government mainly due to drought [3]. Decrease in rainfall, shortage of surface water and ground water abstraction cause depletion in soil moisture. It puts immense pressure on agricultural production which is already in deficit status to meet up continuous demand of food for increasing population of Bangladesh. North western regions are particularly vulnerable to droughts. Each year, during the Kharif season, drought causes significant damage to the $\mathrm{T}$. Aman crop in about 2.32 million ha. In the Rabi season, 1.2 million ha of cropland face droughts of various magnitudes. Apart from loss to agriculture, droughts have significant effect on land degradation, livestock population, employment and health. Between 1960 and 1991, Bangladesh is affected by droughts 19 times. Very severe droughts hit the country in 1951, 1961, 1975, 1979, 1981, 1982, 1984, 1989, 1994, 1995 and 2000. Past droughts have typically affected about 47 percent of the country and 53 percent of the population. Under this circumstance it is high time to develop system to provide early warning about drought to the farmers to reduce/minimize the crop production loss and ensure effective use of irrigation water to maximum possible extent. One of the important contributions of BMD in agriculture sector is to forecast drought through standard precipitation index (SPI). Using SPI data, it is possible to generate early warning and almost appropriate forecast related to drought and weather extremes. It can give advices to the farmers against the disastrous impacts, such as probable water stress, pest infections and diseases, sunshine hours, solar radiation, high temperature, evaporation and humidity, etc. The main objective of this study is to assess the drought indices at Upazila level using SPI data and assist the farmers in coping with climate induced drought through micro-level agricultural water management [4].

\section{Review of Literature}

Generally, the Standardized Precipitation Index is being used worldwide due to its low data requirement and its ability to analyse the various aspects of drought 
based on varying time-scales. However, in arid and semi-arid regions, high temperature along with deficit precipitation is a key factor responsible for the development and progression of droughts. Nowadays, the Standard Precipitation Index (SPI) has become very useful parameter to predict meteorological and agricultural drought over a region [5] [6]. As a probability index of rainfall, it shows negative value for drought and positive value for a wet condition.

The basis of the index is that it builds upon the relationships of drought to frequency, duration and timescales. Compared with PDSI (Palmer drought severity index) [7], SPI is a simpler tool because it is based on rainfall data and with less calculation effort. It allows an analyst to determine the rarity of a drought at a given time scale (temporal resolution) of interest for any rainfall station with historic data. It can also be used to determine periods of anomalously wet events. It is calculated using the following equation;

$$
\mathrm{SPI}=\mathrm{PI}=\frac{X-X m}{\sigma}
$$

$X=$ Precipitation for the station

$X m=$ Mean Precipitation

$\sigma=$ Standardized deviation

Positive SPI values indicate the rainfall is greater than median rainfall and negative values indicate less than median rainfall. In dry condition monitoring, the drought part of the SPI range is divided into near normal conditions $(-1<$ SPI $\leq 1)$, moderately dry $(-1.5<\mathrm{SPI} \leq-1)$, severely dry $(-2<\mathrm{SPI} \leq-1.5)$ and extremely dry (SPI $\leq-2.0)$. A drought event starts when SPI value reaches -1.0 and ends when SPI becomes positive or close to positive again (Table 1).

Drought events are indicated when the results of SPI, for whichever timescale is being investigated, become continuously negative and reach a value of -1 . The drought event is considered to be ongoing until SPI reaches a value of 0 . SPI can be calculated with data missing from the period of record for a location. Ideally, the time series should be as complete as possible, but SPI calculations will provide a "null" value if there are insufficient data to calculate a value, and SPI will begin calculating output again as data become available. SPI is typically calculated for timescales of up to 24 months, and the flexibility of the index allows for

Table 1. SPI values and drought categories in the USA.

\begin{tabular}{cc}
\hline SPI values & Category \\
\hline 2.00 and above & Extremely wet \\
1.50 to 1.99 & Very wet \\
1.00 to 1.49 & Moderately wet \\
-0.99 to 0.99 & Near Normal \\
-1.00 to -1.49 & Moderately dry \\
-1.50 to -1.99 & Severely dry \\
-2.00 and less & Extremely dry
\end{tabular}

Source: National Climatic Data Center, U.S. Department of Commerce, 2012. 
multiple applications addressing events that affect agriculture, water resources and other sectors [8]. Meteorological drought is referred to as a sustained period without significant rainfall [9]. It is considered a deficit of water in comparison with a given reference value with both deficit duration and magnitude taken into account [10]. Hydrological drought may be defined as a period during which stream flows are inadequate to supply established uses under a given water management system [11]. Agricultural drought occurs when rainfall and soil moisture are inadequate for healthy crop growth during the growing season, leading to extreme crop stress and wilt [12].

\section{Methodology}

\subsection{Study Area}

Based on climate change and drought vulnerability, the study areas (e.g. Upazila) selection will be based on the climatic problems and hotspots and expert opinion. Considering all the factors, Paba Upazila of Rajshahi District is thought to be perfect for conducting this study as this Upazila is highly vulnerable to the drought and effect of climatic variability is severe. About $54.68 \%$ of the population of this Upazila is fully dependent on agriculture and that's one of the main reason to select this Upazila for this study as the main objectives include proper water management understanding drought indices. The study area maps have been presented in Figure 1 for a better understanding of the area.

\subsection{Geographic Location}

Paba Upazila of Rajshahi District is located between $24^{\circ} 18^{\prime}$ and $24^{\circ} 31^{\prime}$ north latitudes and between $88^{\circ} 28^{\prime}$ and $88^{\circ} 43^{\prime}$ east longitudes. It has a total area of $280.42 \mathrm{~km}^{2}$. Paba Upazila is bounded by Mohanpur and Tanore Upazilas on

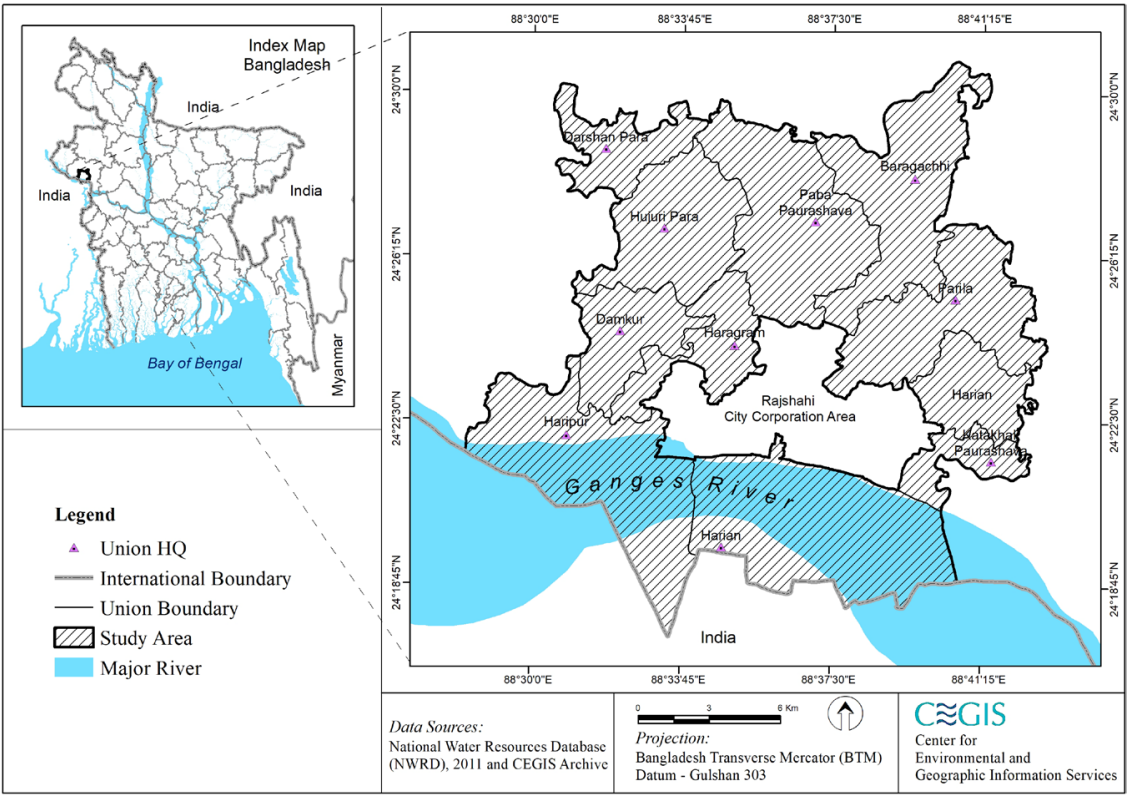

Figure 1. Study area of the proposed project. 
the north, West Bengal state of India and Charghat Upazila on the south, Puthia and Durgapur (Rajshahi) Upazilas on the east, Godagari Upazila on the west. Paba Upazila is mainly comprised of five geological units namely: Alluvial sand, Alluvial Silt, Alluvial silt and clay, Barind Clay residuum and Marsh clay and peat.

\subsection{Rainfall}

Rainfall is the most dominant element of climate in Bangladesh. The rainfall data for the last 30 years (1988-2017) depicts that the highest rainfall occurs in the area from April to October while November to March is drier part of the year with very less rainfall. The analysis of data shows that the monthly average rainfall varies from $252 \mathrm{~mm}$ to $315 \mathrm{~mm}$ in monsoon and the area received the maximum of $763 \mathrm{~mm}$ rainfall in July, 1997. The monthly maximum, minimum and average rainfall is shown in Figure 2. The historical maximum annual rainfall of this station was recorded as $2062 \mathrm{~mm}$ in 1997 and minimum was $791 \mathrm{~mm}$ in 2010. The annual rainfall of this period is shown in Figure 3.

\subsection{Temperature}

The analysis of 30 years (1988-2017) data depicts that the average of maximum temperature in the study area varies from $26^{\circ} \mathrm{C}$ to $39^{\circ} \mathrm{C}$ while the average of minimum temperature varied between $8{ }^{\circ} \mathrm{C}$ and $25^{\circ} \mathrm{C}$. The temperature rises in

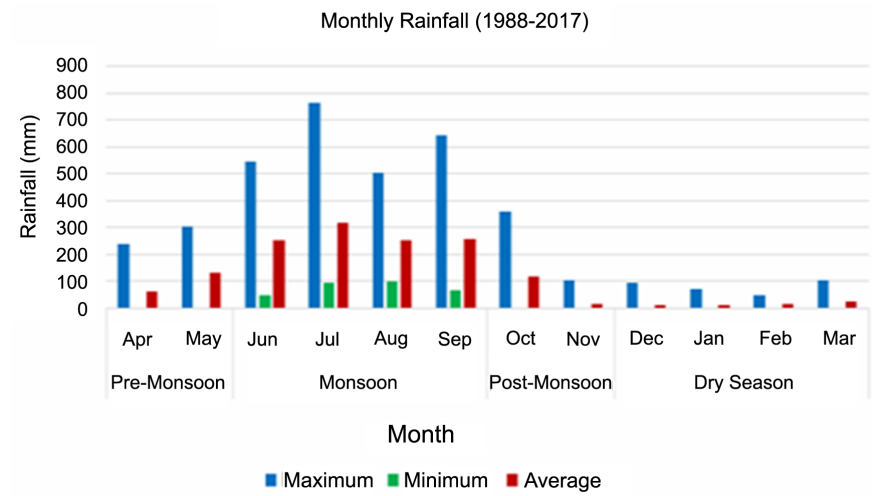

Figure 2. Monthly maximum, minimum and average rainfall.

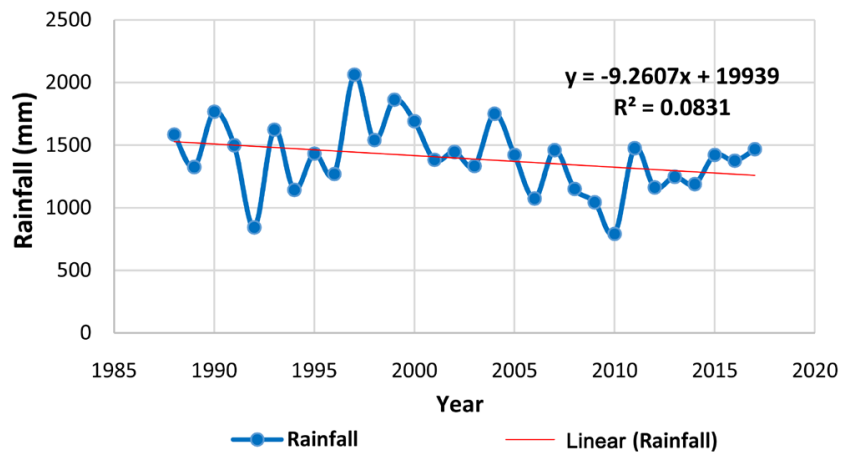

Figure 3. Annual rainfall of during 1988-2017. 
March to October and falls in November to February. The annual maximum and minimum of average temperature of this station were recorded as $32.2^{\circ} \mathrm{C}$ in 2016 and $19.5^{\circ} \mathrm{C}$ in 1989 accordingly. It reveals that the trend of the maximum and minimum temperature is increasing. It is to assume that temperature in summer becomes warmer and in winter it becomes also higher.

\subsection{Relative Humidity}

The value depends on temperature and the pressure of the system of interest. As the temperature of the atmosphere increases, vapor carrying capacity in water increases, and thus the atmospheric vapor pressure also increases for the year of 1988-2017 by Rajshahi BMD. The analysis of the Relative Humidity (RH) data indicates that the maximum Relative Humidity $(\mathrm{RH})$ varies seasonally from $71 \%$ to $90 \%$. The most humid months are from May to January.

\subsection{Topography}

Elevations within the study area range from 12 to $21 \mathrm{~m}+$ PWD with an average elevation of $16.5 \mathrm{~m}+$ PWD. Figure 4 shows the land elevation of the Paba Upazila of Rajshahi District.

\subsection{River Network}

There are Ganges River, Baranai River, Sib River and Hoia River in the study area. But the study area is mainly governed by Ganges River which is shown in Figure 5.

\subsection{Surface Water}

To assess the surface water characteristics of the study area from Figures 6-10,

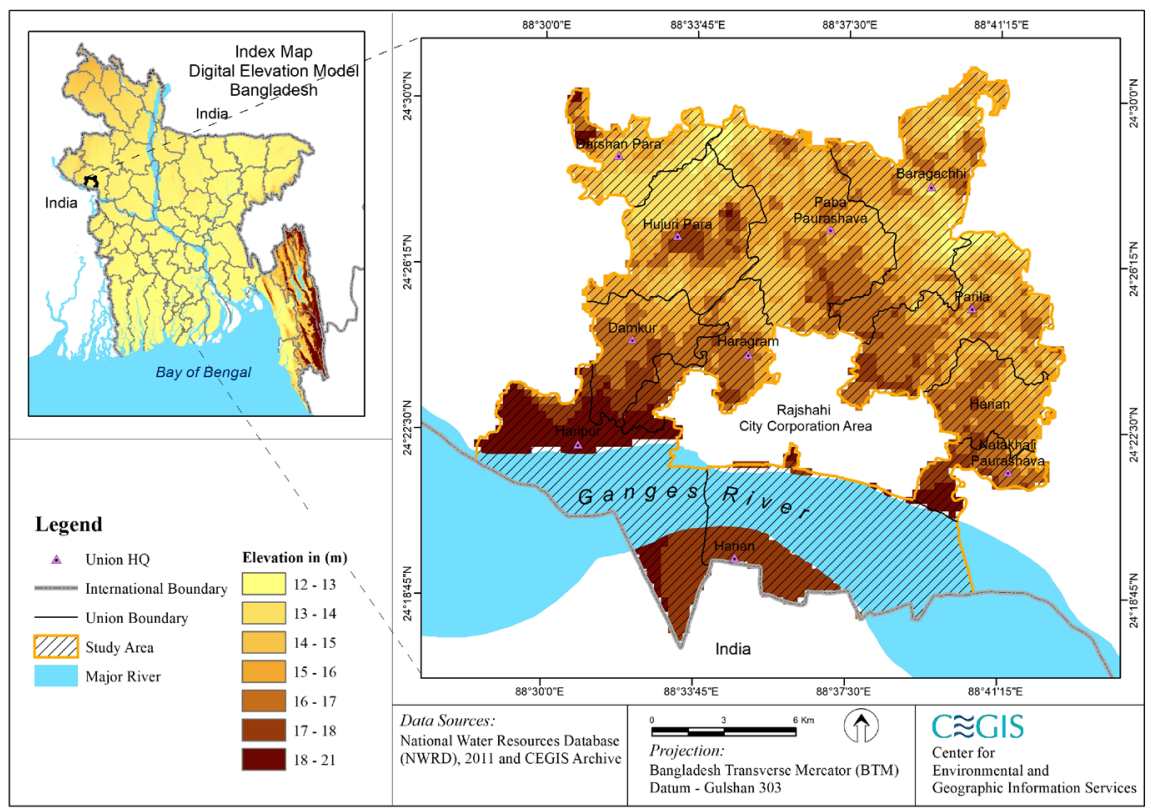

Figure 4. Digital elevation model of the Paba Upazila of Rajshahi district. 


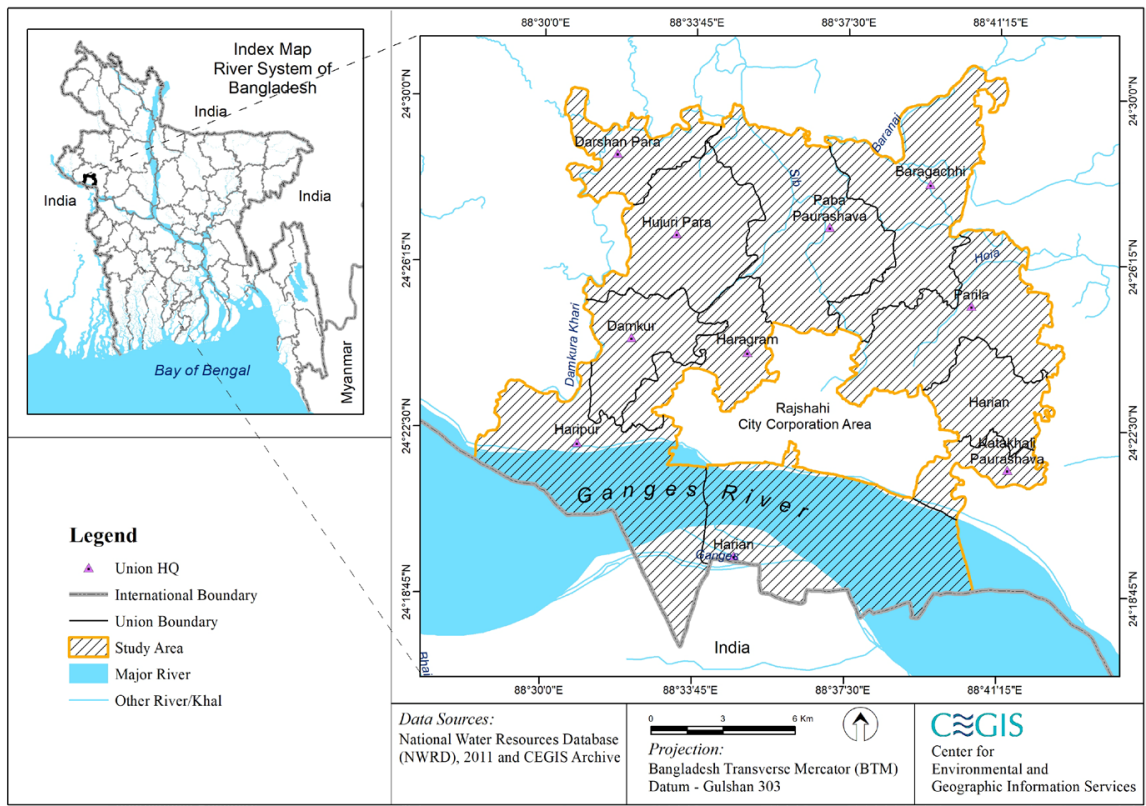

Figure 5. River system of the study area.

Water level at Rampur Boalia (Rajsh) Station

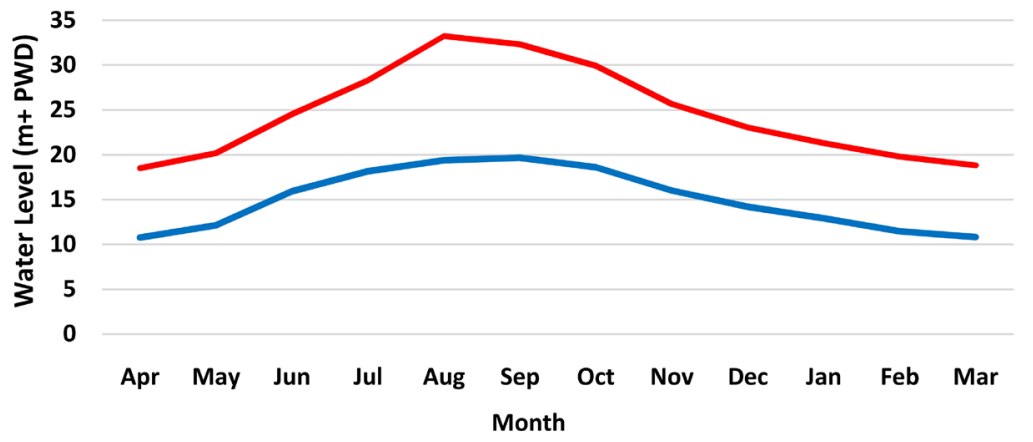

Maximum $\longrightarrow$ Minimum

Figure 6. Monthly water level at Rampur Boalia (Rajesh) station (1980-2009).

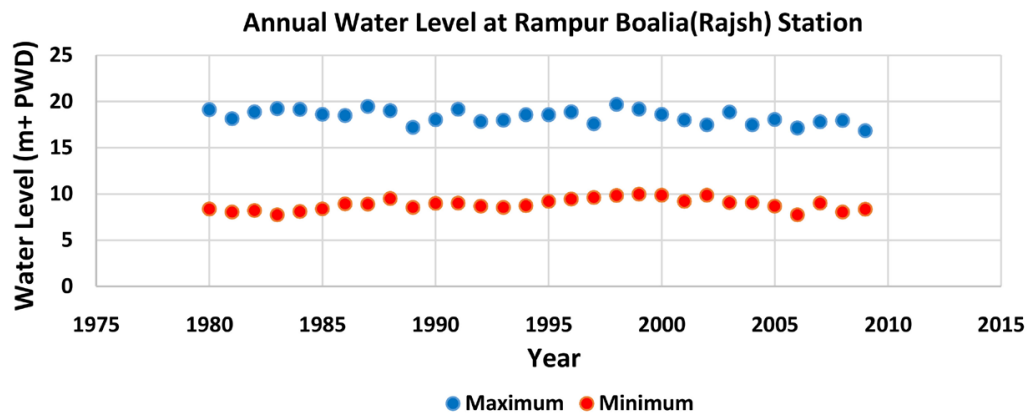

Figure 7. Annual maximum and minimum water level at Rampur Boalia (Rajesh) Station (1980-2009).

two water level data have been collected from non-tidal gauge stations of BWDB for Rampur Boalia (Rajesh) (ID 88) on Ganges River and Nawhata (ID: 261) on Baranai River. 


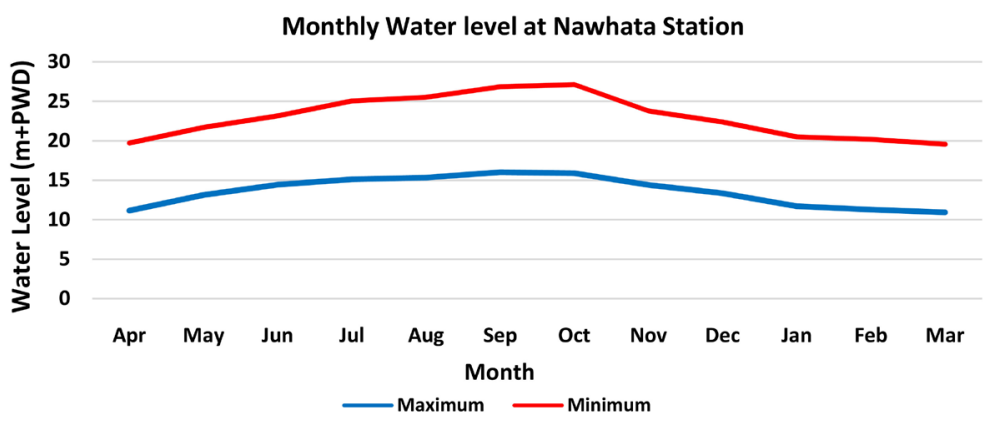

Figure 8. Monthly water level at Nawhata Station (1980-2009).

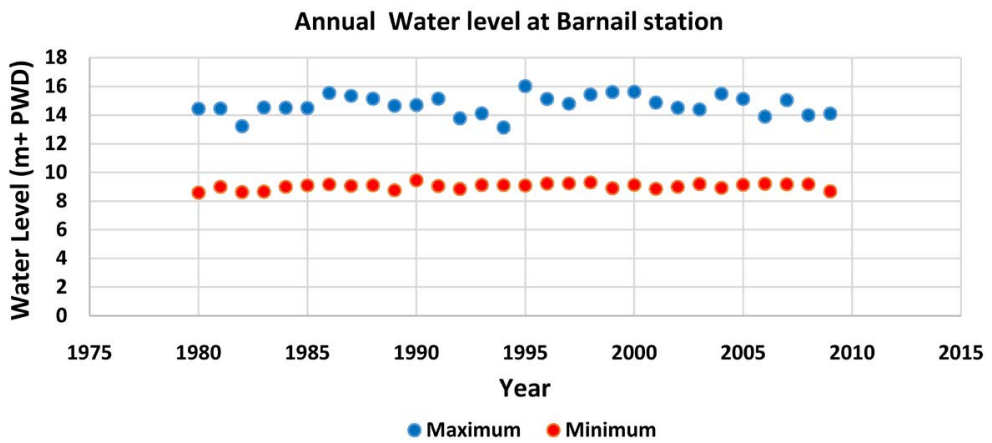

Figure 9. Annual maximum and minimum water level at Nawhata Station (1980-2009).

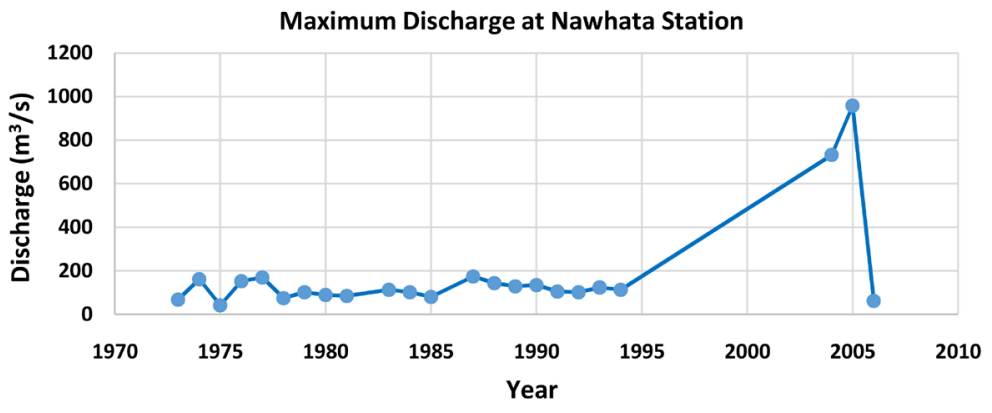

Figure 10. Annual maximum discharge at Nawhata Station (1973-2006).

\subsection{Ground Water}

Monthly variations in ground water levels for year 1984-2013 have been plotted in Figure 11 for the ground water observation well at Paba (named as RAJ038). The variation pattern shows that the Ground Water Table (GWT) ranges vary from $2.71 \mathrm{~m}$ to $7.58 \mathrm{~m}$.

\subsection{Agro-Ecological Zones}

Paba Upazila is mainly comprised of three (3) agro-ecological regions, namely: Active Ganges Floodplain (AEZ-10), High Ganges River Floodplain (AEZ-11) and High Barind Tract (AEZ-26) (BBS, 2017). About $74.20 \%$ of the area is occupied by High Ganges River Floodplain, 23.35\% is Active Ganges Floodplain and $2.45 \%$ is High Barind Tract. The locations of agro-ecological zones are presented in Figure 12. 
Monthly variation of Ground Water Table (1984-2013)

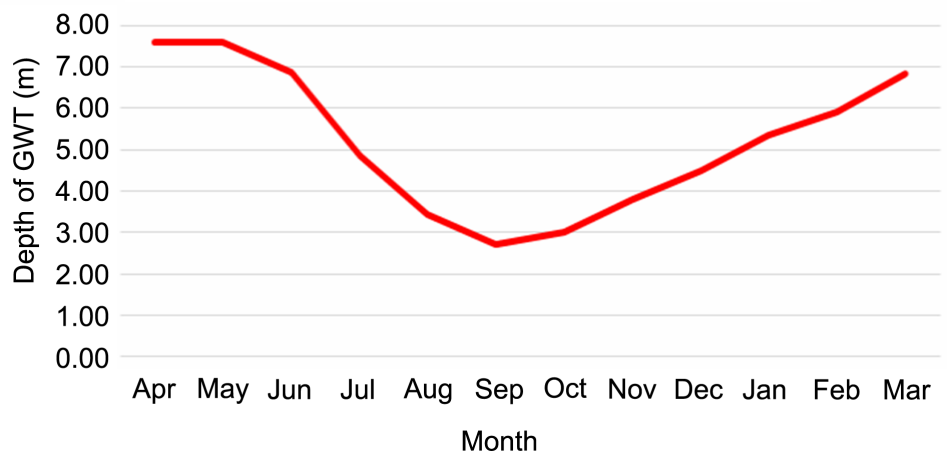

Figure 11. Average monthly variations of ground water table at RAJ003 station.

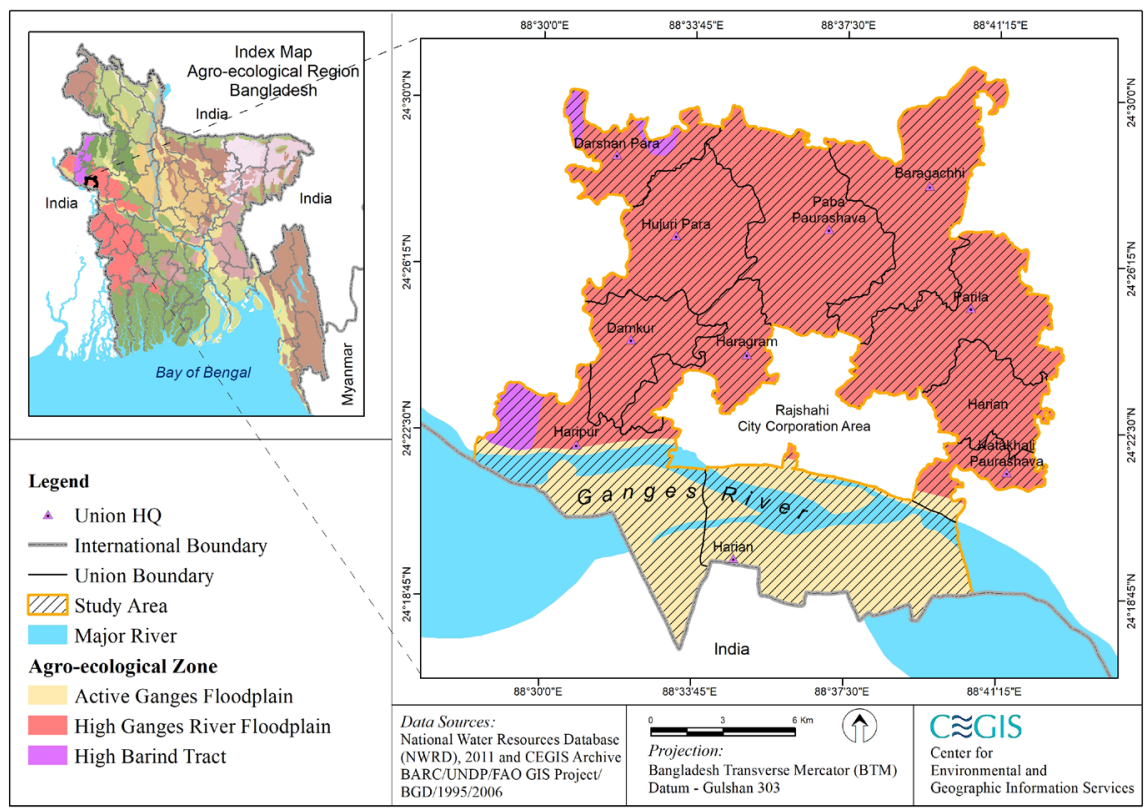

Figure 12. AEZ of study area.

\subsection{Land Type}

Land type of the study area has been presented in Figure 13.

\subsection{Land Use}

Land use of the study area has been presented in Figure 14.

\subsection{Agriculture}

See Table 2.

\subsection{Study Approach}

To accomplish the scope of works, this study will follow a very simple approach. At the very beginning the study team will do an extensive literature review related to droughts and water stress and SPI as well as the existing practices for weather forecasting for agriculture. The steps approach of the study will be 1) 


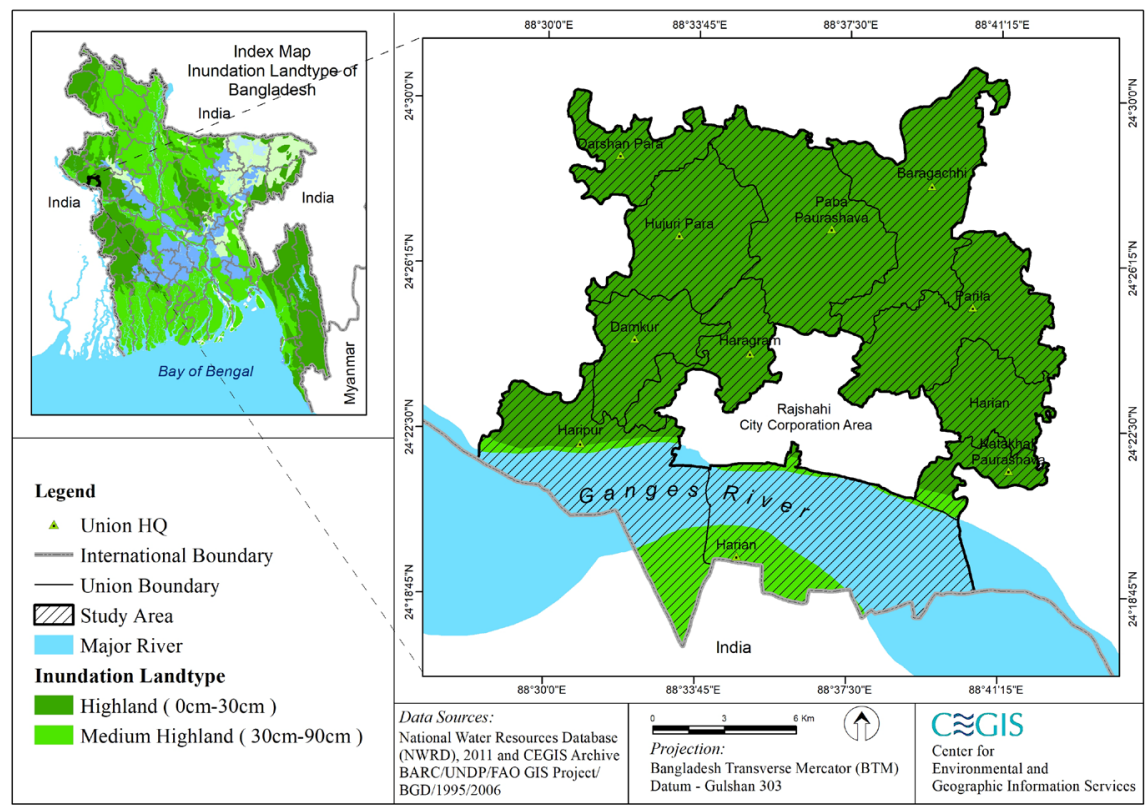

Figure 13. Land type of the study area.

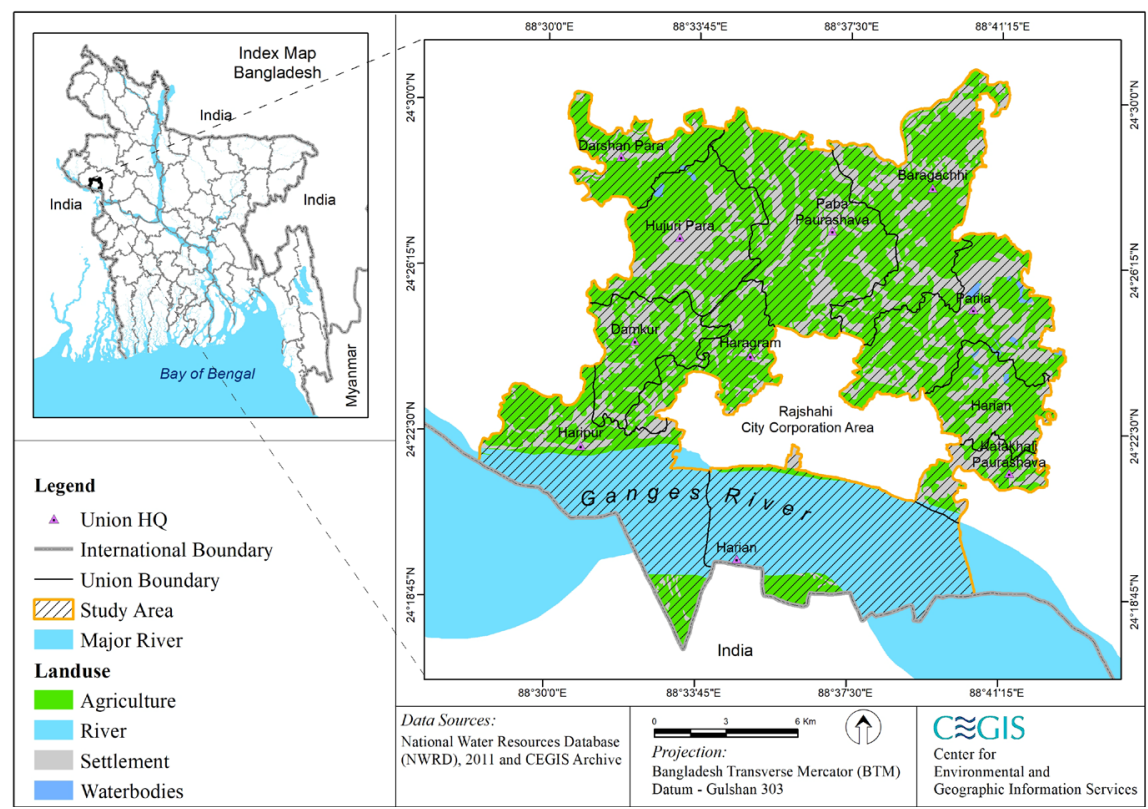

Figure 14. Land use of the area.

Conceptualization of study, 2) Downscaling of data into Upazila level, 3) SPI indexing, 4) Drought indexing and mapping and 5) Technical documentation and dissemination of study outputs. However, the detailed methodology has been described in Figure 15.

\section{Result and Analysis}

\subsection{Monthly Total Rainfall Comparison}

For calculating SPI Index, the only parameter which is required to collect as 
Table 2. Cropping pattern of the study area.

\begin{tabular}{lll}
\hline Kharif-I (March-June) & Kharif-II (July-October) & Rabi (November-February) \\
\hline Fallow & T-aman & HYV-Boro \\
Vegetable & T-aman & Potato \\
Maize & T-aman & Potato \\
Fallow & T-aman & Potato \\
Vegetable & Fallow & Mustard \\
Dhaincha & T-aman & HYV-Boro \\
Jute & T-aman & Wheat \\
Fallow & Vegetable & Onion \\
Fallow & T-aman & Mustard + HYV-Boro \\
Fallow & Vegetable & Lentil \\
Chilli & Fallow & Vegetables \\
Fallow & Fallow & HYV-Boro \\
\hline
\end{tabular}

Source: DAE, PabaUpazila, 2018.

Methodology of the study

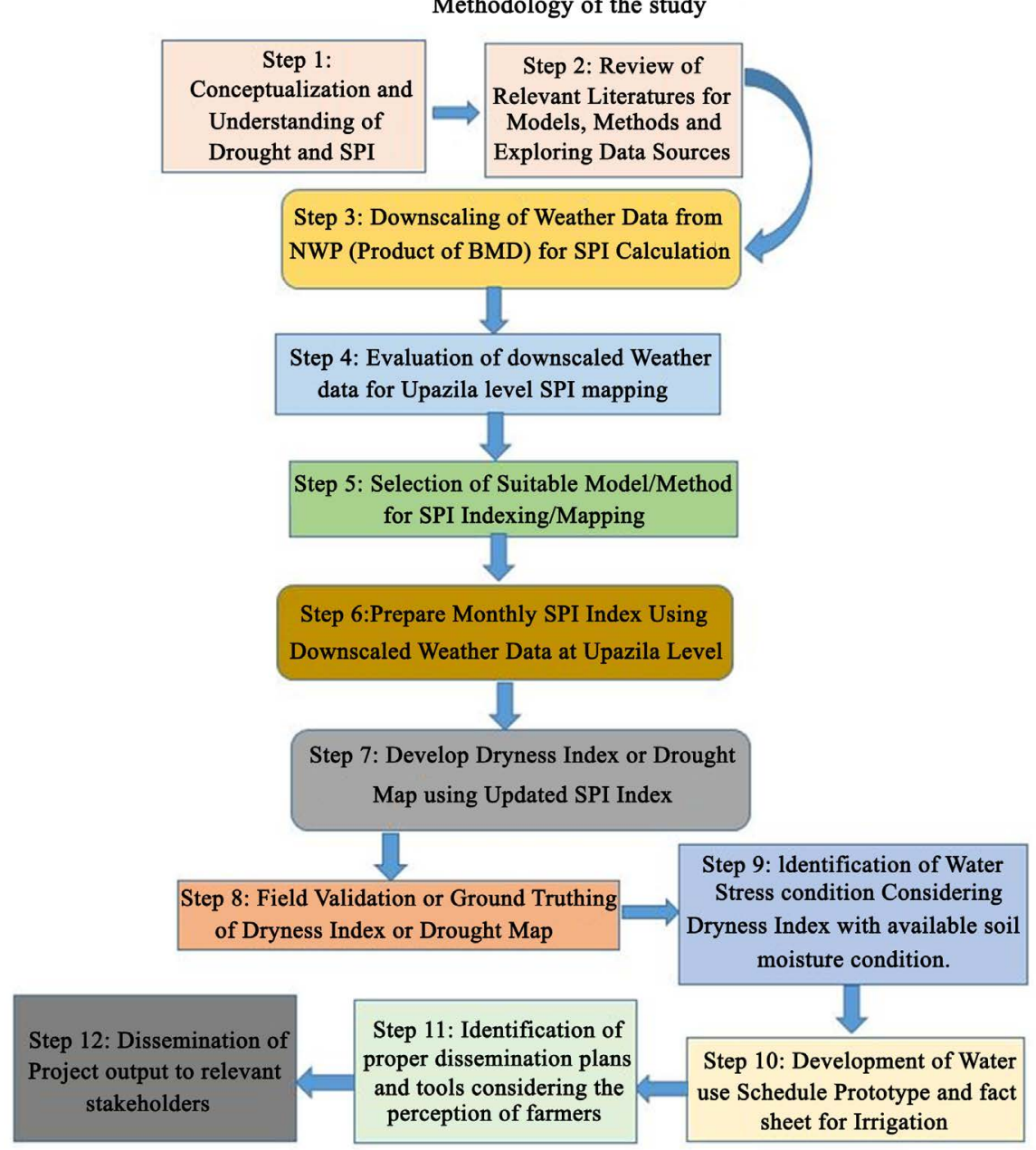

Figure 15. Inductive flow diagram of the methodology. 
primary data is the daily rainfall data. Required data was collected from the Bangladesh Meteorological Department. Two types of rainfall data were collected from BMD. One is the daily Rainfall data for the Rajshahi station as Observed data and Union wise Rainfall as Downscaled data.

For calculation of the SPI Index, the data from 1981-2018 was used. On the other hand, for showing the monthly variation of rainfall, the recent year's data (2014-2018) was considered. The Sum of the monthly rainfall is shown in Figures 16-19, which indicates the comparison between highest and lowest amount of rainfall over the 5-year period. Also this graph shows the union wise variation of rainfall with each other and the observed data. As it is already known the study area Paba Upazila Rajshahi is comprised of 12 unions so for better representation in the graph 12 unions were divided into 4 groups to compare the variation with Observed data (Rajshahi Station). The 4 groups of the unions are-Harian 02, Harian 01 and Noahata Paurashava (Group 1), Parilla, Katakhali Paurashava and Haripur (Group 2), Baragachi, Darshan Para and Damkur (Group 3) and Haragram 01, Haragram 02 and Hujuri Para (Group 4).

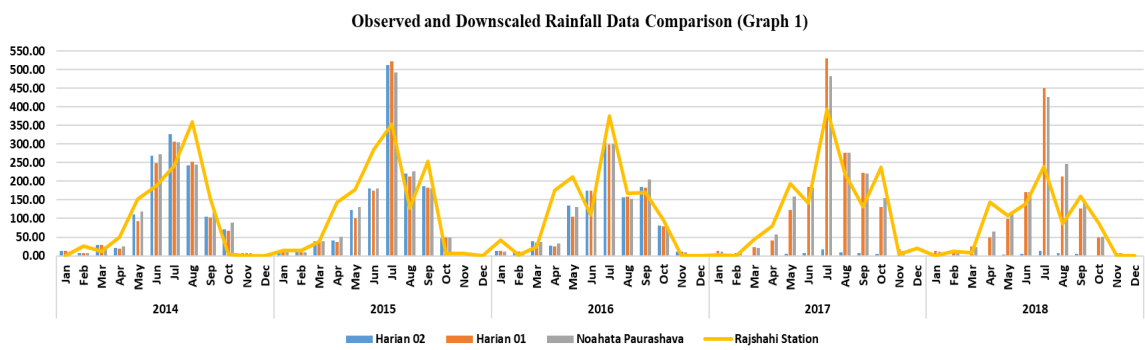

Figure 16. Observed and downscaled (union wise) monthly rainfall data comparison-1.

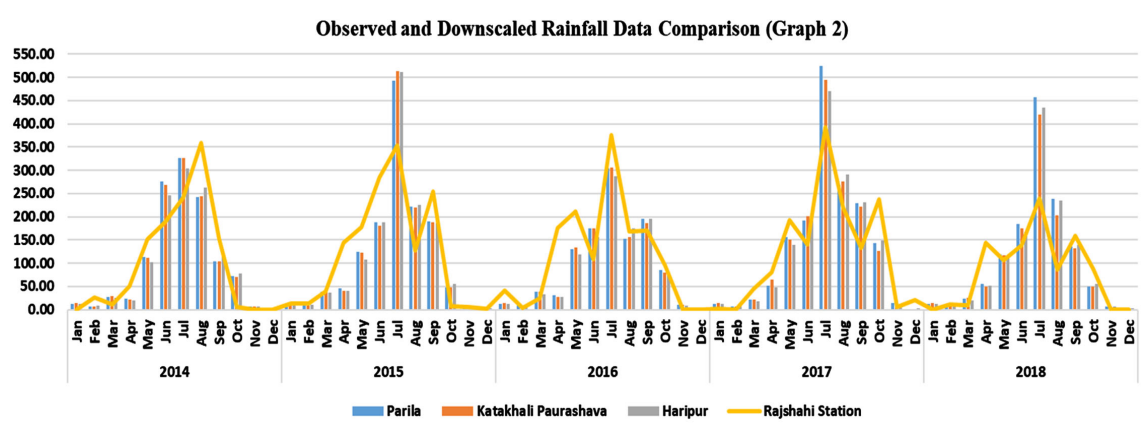

Figure 17. Observed and downscaled (union wise) monthly rainfall data comparison-2.

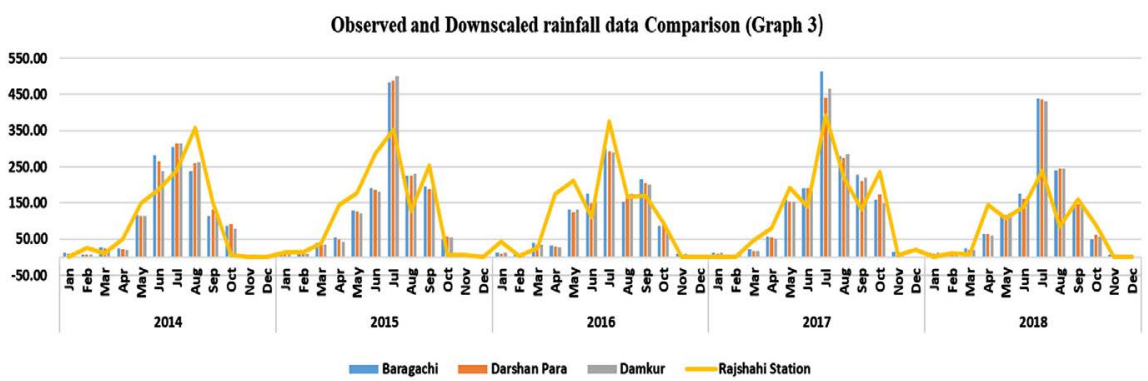

Figure 18. Observed and downscaled (union wise) monthly rainfall data comparison-3. 


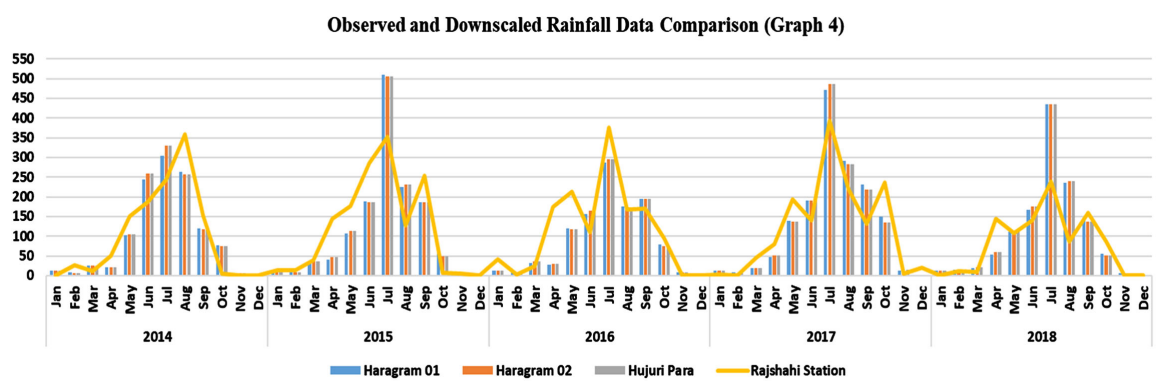

Figure 19. Observed and downscaled (union wise) monthly rainfall data (total) comparison-4.

The monthly total rainfall of these groups of unions was compared with the observed rainfall. For all the graphs the variation pattern between the observed and downscaled data is almost identical. For the month of May to October the value of Downscaled rainfall data is quite high and often exceeds the observed value. This may occur due to the process followed while downscaling. The rainfall value is in 100 to less than $550 \mathrm{~mm}$ range approximately for the year 2015, 2017 and 2018, while in 2014 and 2016 the rainfall is quite less in the yearly peak time of rainfall (less than $250-350 \mathrm{~mm}$ ). The range of rainfall value is between $0-50$ $\mathrm{mm}$ in the dry and winter season (November to March). The variation of rainfall between the unions is very small and therefore it can be called minimal or insignificant.

\subsection{Monthly Average Rainfall Comparison}

The Monthly Average Rainfall is also represented in Figures 20-23 following the same procedure of dividing the unions into four groups along with the observed data. The 4 groups of the unions are-Harian 02, Harian 01 and Noahata Paurashava (Group 1), Parilla, Katakhali Paurashava and Haripur (Group 2), Baragachi, Darshan Para and Damkur (Group 3) and Haragram 01, Haragram 02 and Hujuri Para (Group 4).

Rainfall is a parameter which is highly station based. For that reason, it is difficult to take an average of rainfall and may often be misleading for the observant. However, monthly average rainfall gives one indication about the rainfall intensity in a particular area throughout the month. For example, in the case of these unions it can be said that the rainfall in the month of November to February the rainfall is very less and can be called no rain situation. It also indicates the dry situation. On the other hand, the month of June, July and August the rainfall is quite high and indicates the wetness.

For the average rainfall the rainy season (May to October) the monthly average rainfall is approximately 3 to less than $18 \mathrm{~mm}$ on the other hand during November to April it is 0 to less than $3 \mathrm{~mm}$. The trend followed by the total rainfall, is also governed here (i.e. the rainfall is less in the 2014 and 2016 rainy season).

\subsection{Monthly Standard Precipitation Index Calculation}

Monthly Standard Precipitation Index calculated using the rainfall data which is 


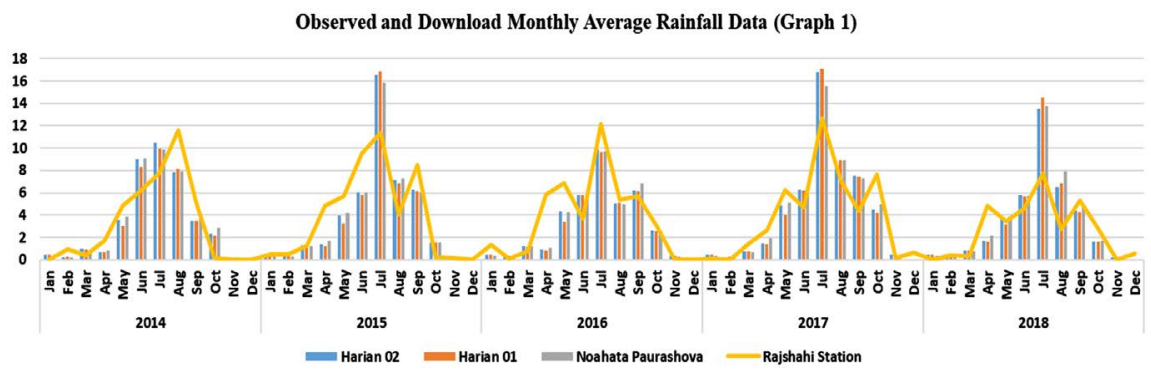

Figure 20. Observed and downscaled (union wise) monthly average rainfall data comparison-1.

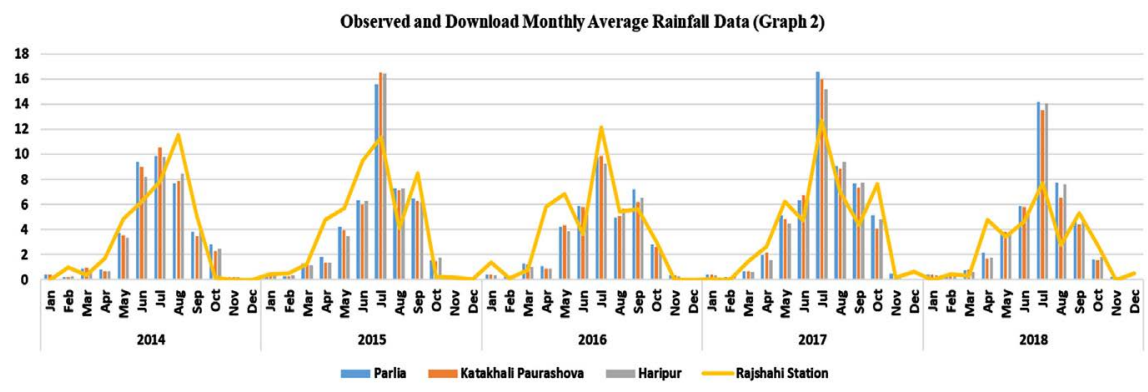

Figure 21. Observed and downscaled (union wise) monthly average rainfall data comparison-2.

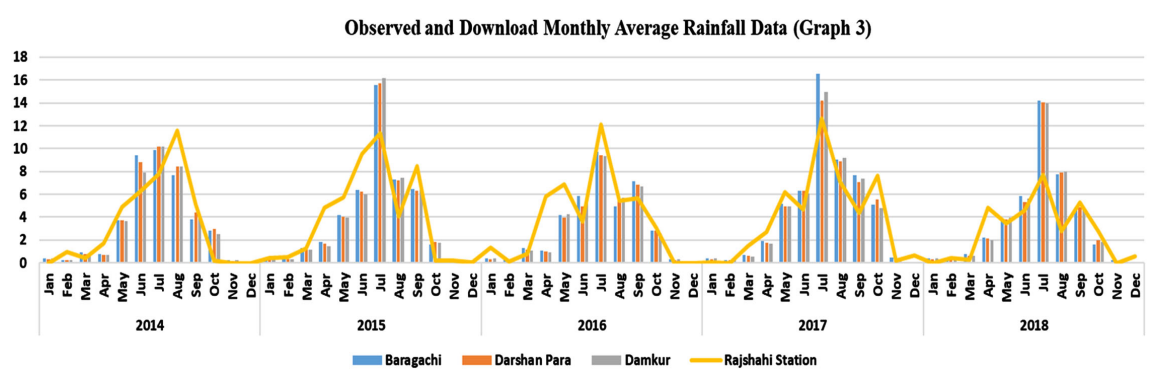

Figure 22. Observed and downscaled (union wise) monthly average rainfall data comparison-3.

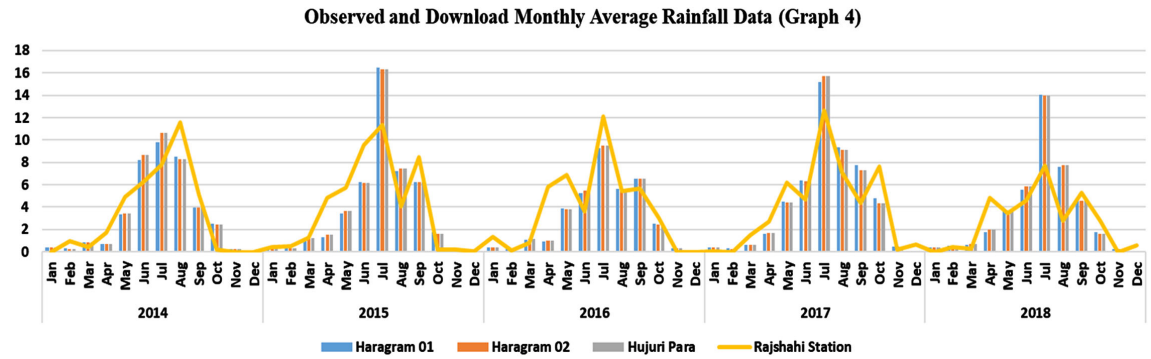

Figure 23. Observed and downscaled (union wise) monthly average rainfall data comparison-4.

shown in Figure 24. For calculating the SPI value, a very user friendly and widely used index calculating software was used. The software is known as the DrinC software. This software can be used for calculating SPI Index for monthly, 3 monthly, 6 monthly, 12 monthly and higher period of time. For Calculating 


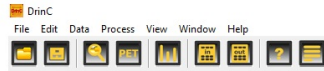

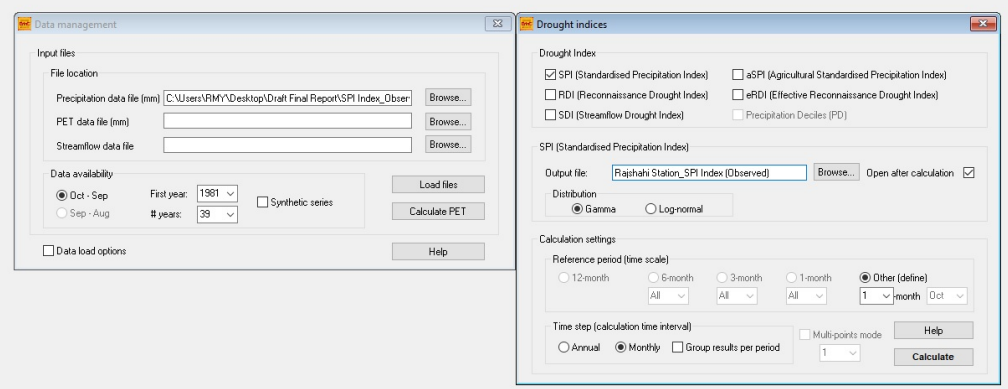

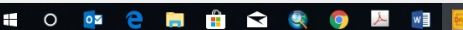

Figure 24. Calculation of monthly index from rainfall data.

Monthly SPI Index, daily rainfall data is prepared monthly according to the Hydrological Year (HY) followed by the software. For every union separate monthly rainfall data (Sum) was prepared and Monthly SPI Index was the output after putting the command calculated in DrinC. Gammma distribution was used as the recommendation of the BMD experts.

\subsection{Comparison of Observed and Downscaled SPI}

The Monthly SPI Index was calculated using DrinC software. For all the downscaled data (Union wise) and Observed data the Index was found. The Union wise Index and Average SPI Index among the Unions were compared with the Index calculated from the Observed data. The standard Precipitation index obtained from each union (Baragachhi, Damkur, Darsha Para, Haragram 1, Haragram 2, Harian 1, Harian 2, Haripur, Hujuri Para, Katakhali Paurashava, Noahata Paurashava and Parilla) was compared with the Index obtained from the observed data. From the representation and trend line shown in the figures (Figures 25-37) it can be said that the variation of Observed and downscaled data is not extreme and this statement is also supported by the $\mathrm{R}^{2}$ value. The statistical $\mathrm{R}^{2}$ value shows the variation among two sets of data. The more it is close to 1 , it is more scattered and skewed. On the other hand, the more it is close to 0 it is uniform. Here it can be said that the observed and Union wise downscaled data is very close and not scattered.

\subsection{Preparation of Drought Map}

The Monthly SPI Index values calculated for all the Unions, the Master Table of Monthly SPI value was prepared. For the Interpolation of Index Values, the Kriging and Spline Method was used. As the data is downscaled to union wise it gives better result for both the Kriging and Spline Interpolation. For preparing the drought map the classification suggested by the national climatic data center, US Department of Commerce, 2012 was followed. 


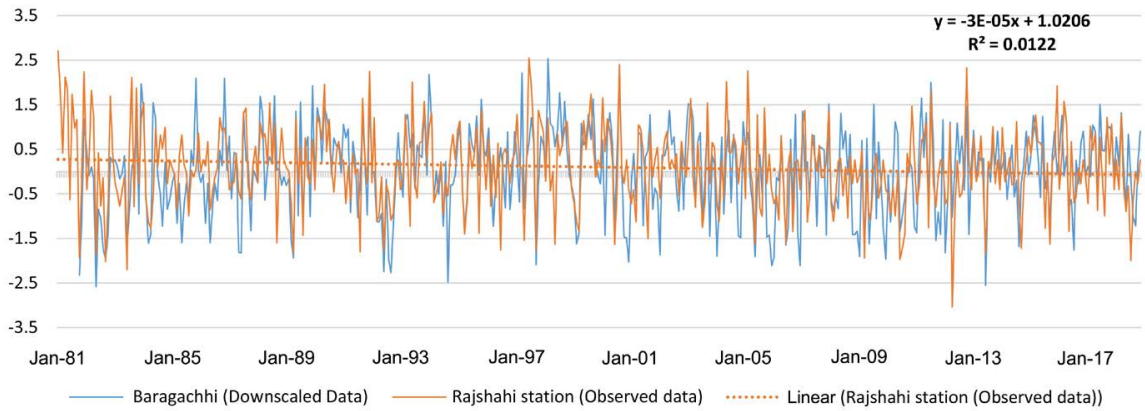

Figure 25. Comparison of observed and downscaled (union wise) monthly index-1.

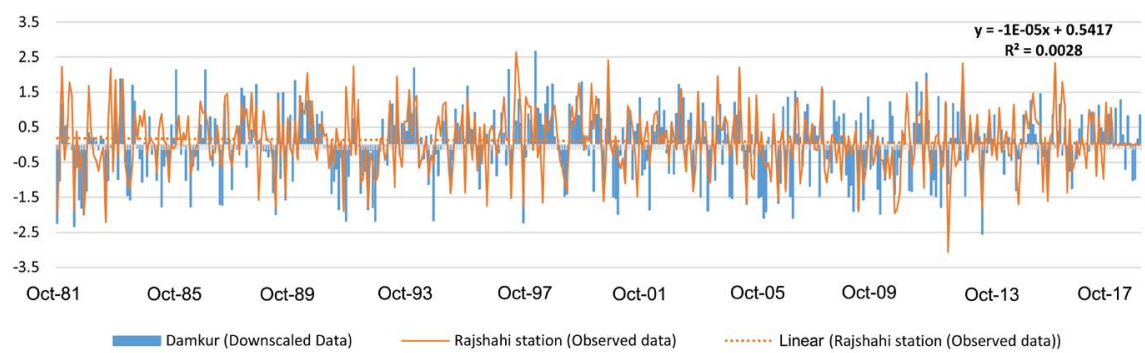

Figure 26. Comparison of observed and downscaled (union wise) monthly index-2.

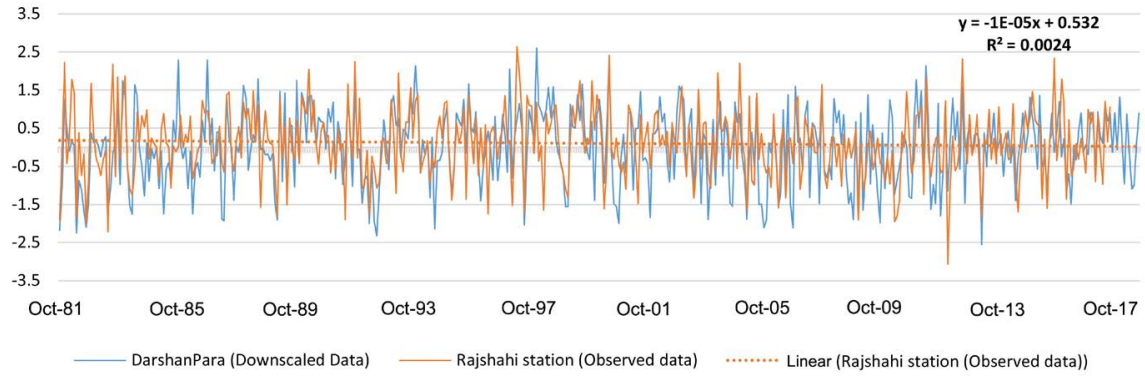

Figure 27. Comparison of observed and downscaled (union wise) monthly index-3.

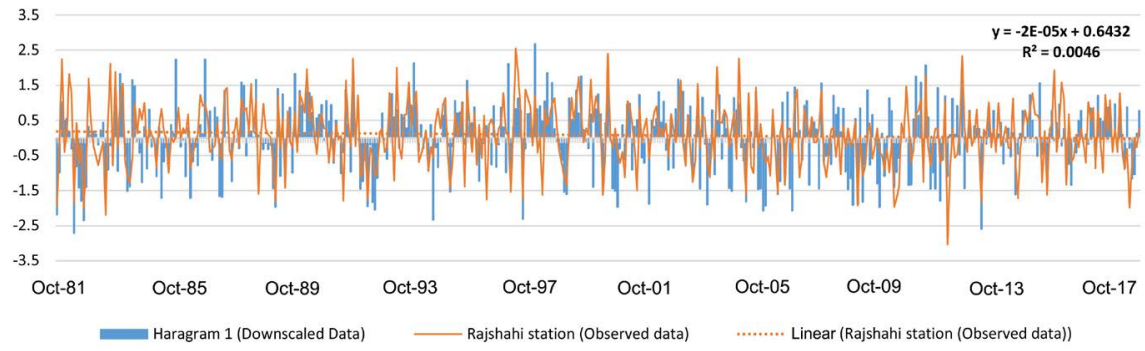

Figure 28. Comparison of observed and downscaled (union wise) monthly index-4.

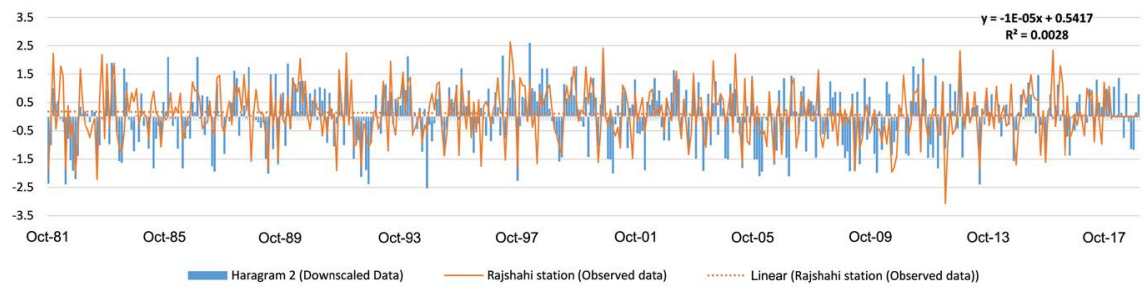

Figure 29. Comparison of observed and downscaled (union wise) monthly index-5. 


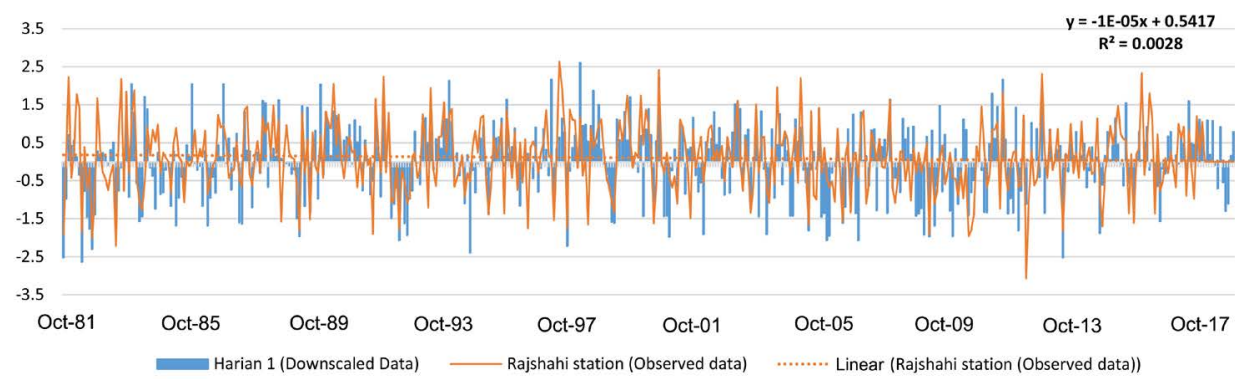

Figure 30. Comparison of observed and downscaled (union wise) monthly index-6.

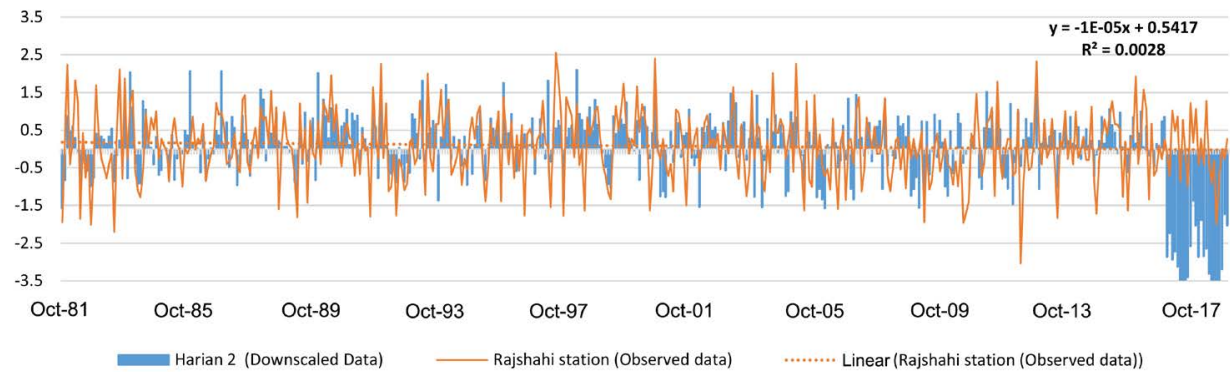

Figure 31. Comparison of observed and downscaled (union wise) monthly index-7.

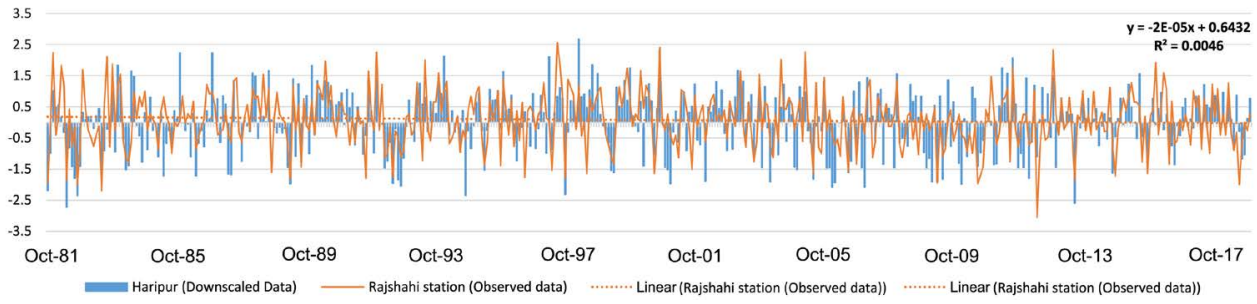

Figure 32. Comparison of observed and downscaled (union wise) monthly index-8.

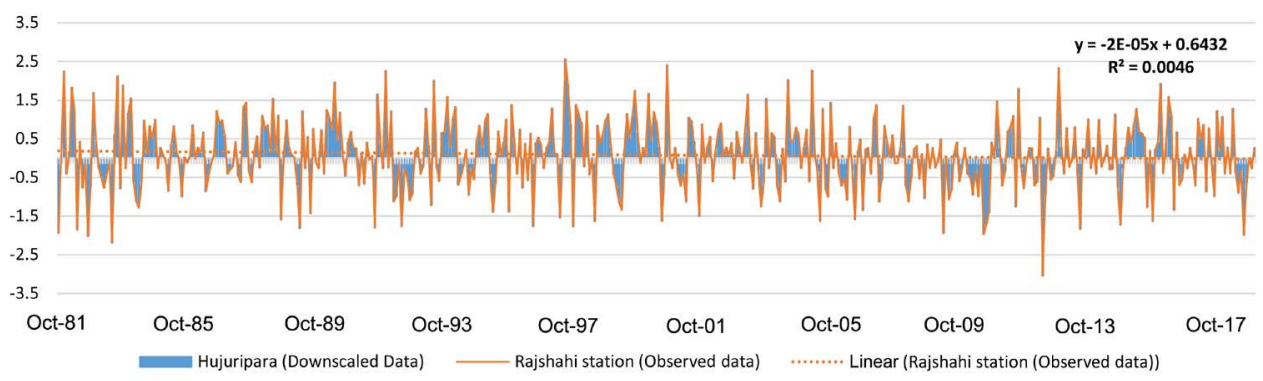

Figure 33. Comparison of observed and downscaled (union wise) monthly index-9.

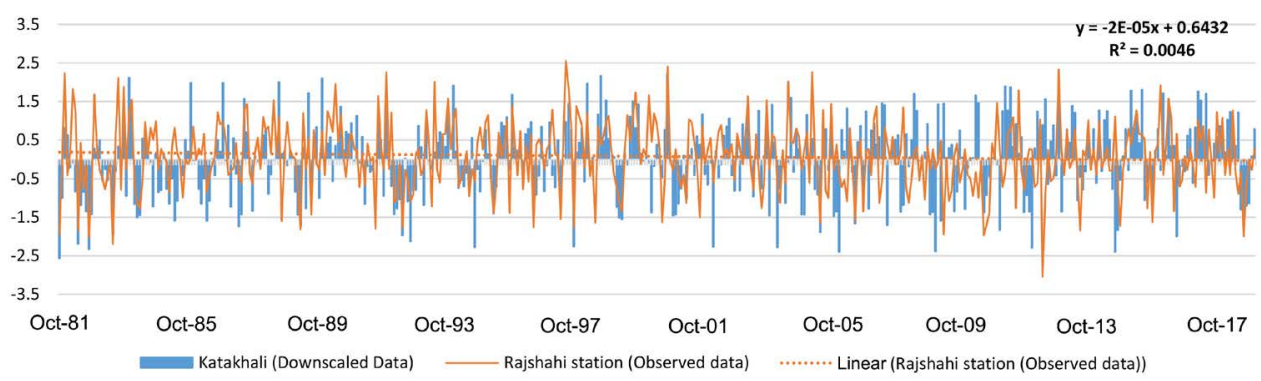

Figure 34. Comparison of observed and downscaled (union wise) monthly index-10. 


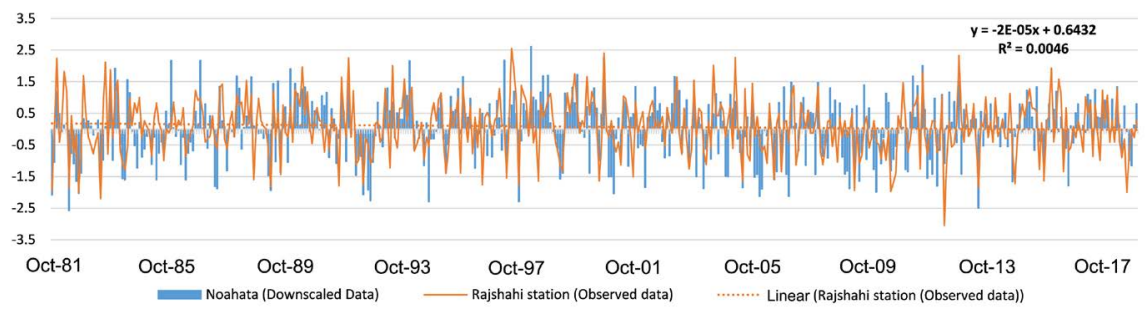

Figure 35. Comparison of observed and downscaled (union wise) monthly index-11.

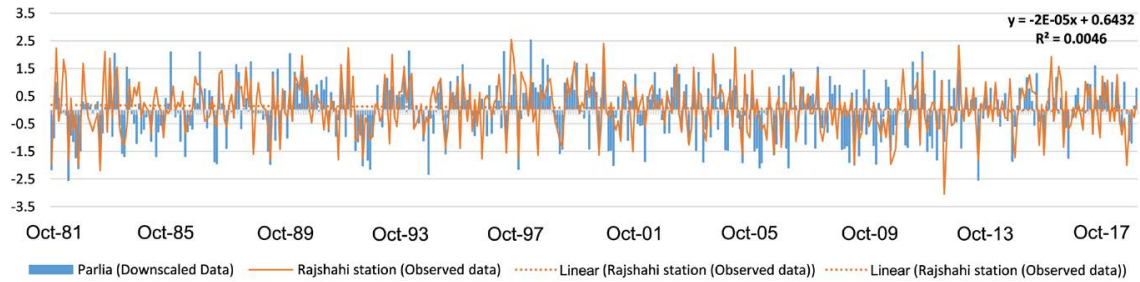

Figure 36. Comparison of observed and downscaled (union wise) monthly index-12.

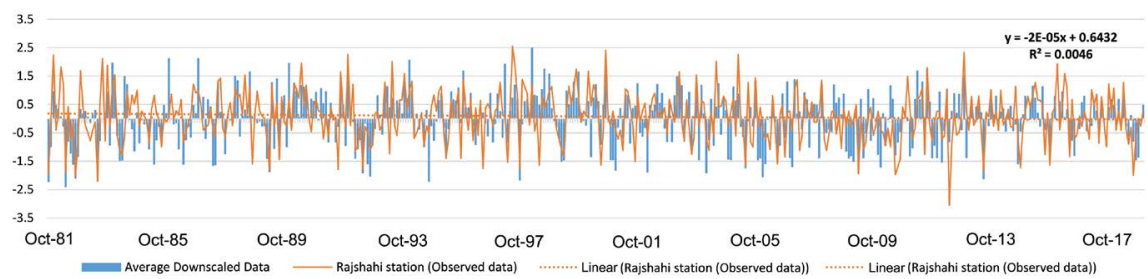

Figure 37. Comparison of observed and average downscaled monthly index-13.

The Monthly variation of the drought map shows the Harian (Station Id: Harian 2) area is the most vulnerable area in case of low rainfall. It is also observed the Kriging interpolation gives more uniform result than spline interpolation. Though the Study area is very small and only an Upazila, still the map shows different SPI range in different areas which is obviously more precise and well distributed. The difference of the values between Spile and Kriging Interpolation is discussed in the next subsection.

Figure 38 and Figure 39 represent the Monthly Drought map for the Month of February to June in both the Kriging and Spline Interpolation method. The Monthly variation and variation due to the change in method is quite significant.

The Drought Map prepared following Kriging Interpolation and Spline Interpolation varies significantly. The area covered in these two processes quite different. For comparing the area covered by the SPI range, the Drought map of the month of June 2018 is taken. Here in Figure 40, we see the difference in the SPI range and area Coverage. The area coverage of Spline and Kriging interpolation is shown in Table 3.

In the Spline Interpolation total study area is distributed into 7 classes of SPI range on the other hand in Kriging interpolation the study area is divided into 5 categories. The extreme dry condition also governed for 3962.25 ha area in Spline interpolation case on the other hand in Kriging interpolation it is 3530.75 ha. 


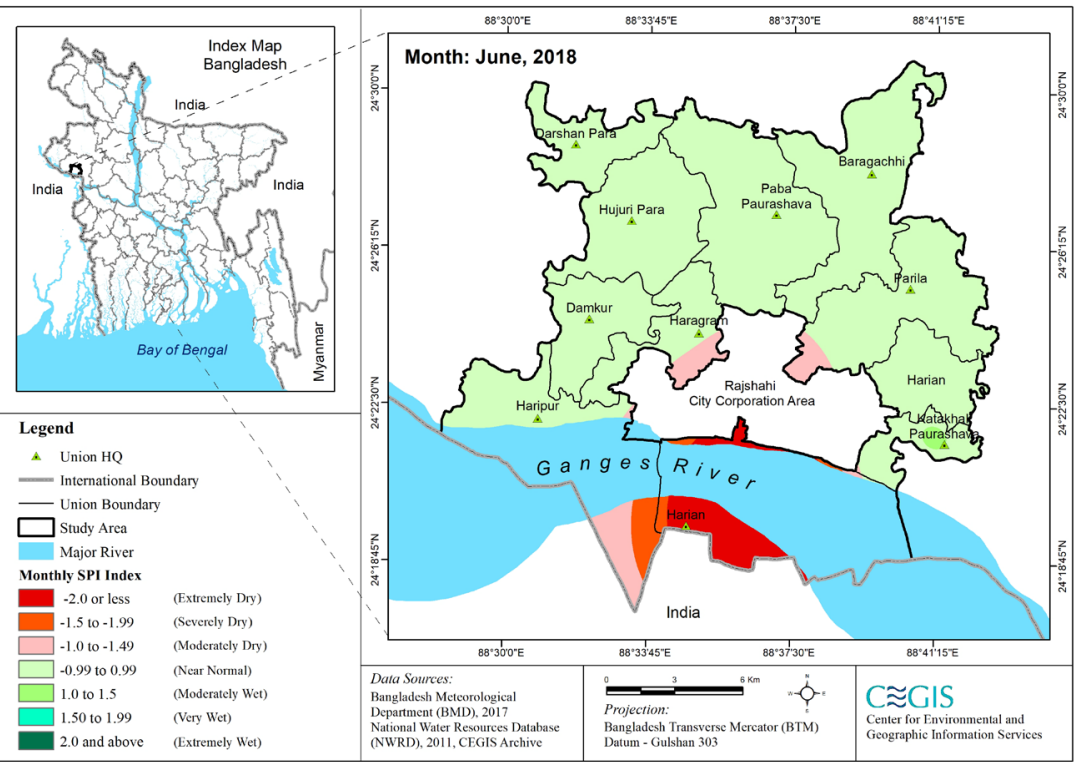

Figure 38. Monthly standard precipitation index map-Kriging interpolation (June, 2018).

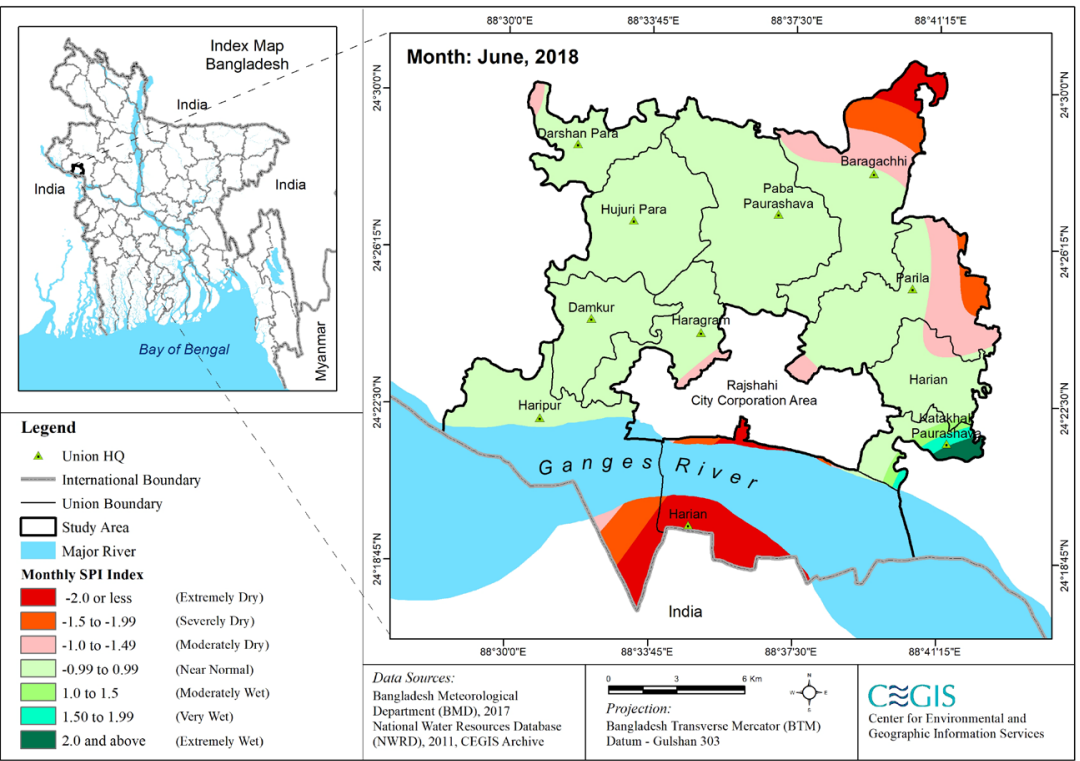

Figure 39. Monthly standard precipitation index map-Spline interpolation (June, 2018).

Table 3. Area coverage of Kriging and Spline interpolation.

\begin{tabular}{cccc}
\hline SPI Index Range & Category & $\begin{array}{c}\text { Kriging Interpolation } \\
\text { Area (ha) }\end{array}$ & $\begin{array}{c}\text { Spline Interpolation } \\
\text { Area (ha) }\end{array}$ \\
\hline-2.00 or less & Extremely dry & 3530.75 & 3962.25 \\
-1.50 to -1.99 & Severely dry & 1281 & 1786.75 \\
-1.00 to -1.49 & Moderately dry & 2175.75 & 3007.75 \\
-0.99 to 0.99 & Near Normal & 23,389 & $20,740.25$ \\
1.00 to 1.49 & Moderately wet & 82.5 & 352.25 \\
1.50 to 1.99 & Very wet & - & 271 \\
2.00 and above & Extremely wet & - & 338.75 \\
\hline
\end{tabular}




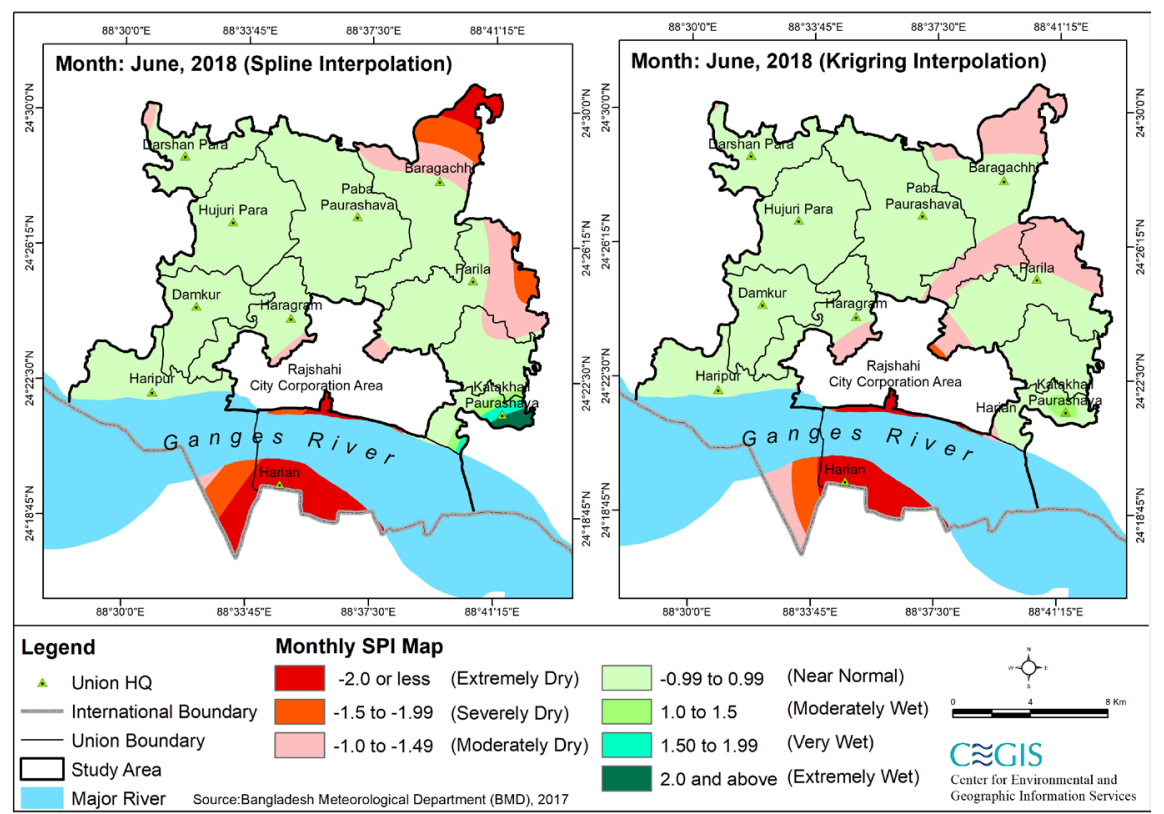

Figure 40. Comparison of monthly SPI map-Spline and Kriging interpolation (June, 2018).

\section{Conclusion}

Weather forecast for agriculture sector should be of prime importance. An effective and user friendly early warning system will help to improve agricultural production which will contribute to achieving the food security of the country. Therefore, it is very crucial to ensure the best utilization of the existing forecasting message. To achieve this target, end users should be well aware of and informed about the services. Moreover, training should be provided to the farmers to understand the linkage of the weather with the agricultural practices and the benefits of agro-meteorological forecasting. The farmers should also train up on the response mechanism after receiving the forecast. In addition to the farmers, the relevant departments are also equipped with providing training for better application of knowledge and information into practice. Moreover, institutionalization of the forecast and proper networking among the departments are also very vital for sustainability and best utilization of the forecast.

\section{Limitations}

1) The study going to generate SPI and Drought index using the moderate resolution downscaled climate data.

2) Generation of water stress map and use for irrigation scheduling is new concept. This output will be prototype.

3) The flexibility of SPI to be calculated based on the downscaled data where maybe many missing values may contain. This may create problems to generate quality outputs or expected result.

4) The positive issue is that the output of the study will give researchers, planners and decision maker's new arena of local level water management issues 
using SPI or drought index to be generated under this study.

\section{Conflicts of Interest}

The authors declare no conflicts of interest regarding the publication of this paper.

\section{References}

[1] Ramamasy, S. and Baas, S. (2007) Climate Variability and Change: Adaptation to Drought in Bangladesh. A resource Book and Training Guide. Case Study 9. Institutions for Rural Development. ADPC. FAO, 2.

[2] Faroque, M., Asaduzamman, M. and Hossain, M. (2013) Sustainable Agricultural Development under Climate Change in Bangladesh. Journal of Science Foundation, 11, 17-28. https://doi.org/10.3329/jsf.v11i1.19396

[3] Kashem, M. and Faroque, M. (2013) A Country Scenarioes of Food Security and Governance in Bangladesh. Journal of Science Foundation, 9, 41-50. https://doi.org/10.3329/jsf.v9i1-2.14646

[4] Center for Environmental and Geographic Information Services (CEGIS) (2013) Vulnerability to Climate Induced Drought Scenario and Impacts.

[5] Angelidis, P., Maris, F., Kotsovinos, N. and Hrissanthou, V. (2012) Computation of Drought Index SPI with Alternative Distribution Functions. Water Resources Management, 26, 2453-2473. https://doi.org/10.1007/s11269-012-0026-0

[6] Bordi, I. and Sutera, A. (2008) Drought over Europe in Recent Years. Options Méditerranéennes, Series A No. 80, 63-68.

[7] Palmer, W.C. (1968) Keeping Track of Crop Moisture Conditions, Nationwide: The New Crop Moisture Index. Weatherwise, 21, 156-161. https://doi.org/10.1080/00431672.1968.9932814

[8] World Meteorological Organization (WMO) and Global Water Partnership (GWP), (2016) Handbook of Drought Indicators and Indices (M. Svoboda and B.A. Fuchs). Integrated Drought Management Programme (IDMP), Integrated Drought Management Tools and Guidelines Series 2. Geneva.

[9] Linsley, R.K., Kohler, M.A., et al. (1958) Hydrology for Engineers. McGraw-Hill Book Company, New York.

[10] Downer, R.N., Siddiqui, M.M. and Yevjevich, V. (1967) Application of Runs to Hydrologic Droughts. Proceedings of the International Hydrology Symposium, Fort Collins, 6-8 September 1967, 496-505.

[11] Linsley Jr., R.K., Kohler, M.A. and Paulhus, J.L.H. (1975) Hydrology for Engineers. 2nd Edition, McGraw Hill, KoguKusha, Tokyo.

[12] Venkateswarlu, J. (1987) Technological and Sociopolitical Adaption and Adjustment to Drought, the Indian Experience. Report Planning for Drought, Westview Press/Boulder and London, UNEP, USA, 391-408. 